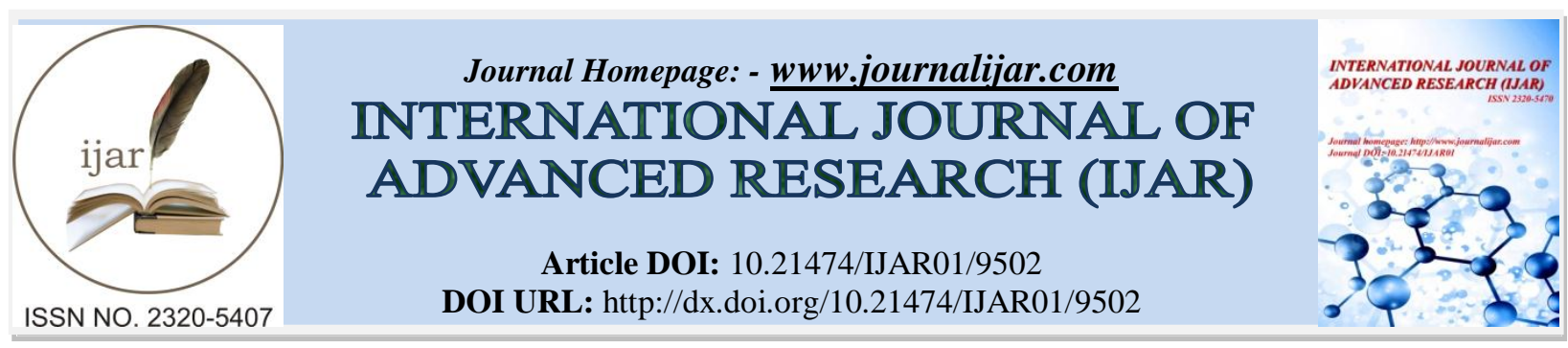

RESEARCH ARTICLE

\title{
ANALYSIS OF FACTORS ADHERENCE TO SAFE INJECTION PRACTICE PROCEDRUES AMONG NURSES HEALTHCARE CENTER QATAR.
}

\section{Sobur Setiaman, Kohar Sulistyadi and Syahfirin Abdullah.}

Post Graduate School, Sahid University Jakarta, Indonesia.

\section{Manuscript Info}

Manuscript History

Received: 06 June 2019

Final Accepted: 08 July 2019

Published: August 2019

Key words:-

Keyword: Nurses, safe injection practice, nurses behavior.

\section{Abstract}

Introduction: Injection practices was common medical procedure done by nurses according doctor's prescription. In nursing process, injection practice is part of nursing intervention, but injection practices was risky for the health care workers. Mandal J., (2013) reported needle stick injury was happened to the nurses, $18 \%$ due disposal of the needle, and $15 \%$ while draw the blood for laboratory study. According Strank, J., (2013) adherence to the work procedure influence by behavior factors, component the behavior ass follow: 1 . attitude; 2. motivation; 3. perception; 4. memory of procedure; 5. individual characteristics; and 6. social background. Based on the theory of Lawrence Green cited behavior influence by 3 factors: 1 . Predisposition factors; 2. Enabling factor; 3 . Reinforcing factor.

Aim of research: of the research were to finding out of the factors influence of adherence to safe injection practice among the nurses at healthcare center X Qatar.

Method: Type of the research was observational analytic quantities of the analytic description, using cross sectional approach. 9 variable latent with 56 variable indicator. Size of sample were 114 nurses. Data analytic with using PLS-SEM.

Result: T-statistic value on variable culture 2.94; environment 1.99; work procedure 3.81 and supervisory 3.10. T-statistic of Individual characteristic, work facility, attitude, and knowledge bellow 1.96. $\mathrm{R}^{2}$ variable adherence were showed $96.05 \%$ with $\mathrm{Q}^{2} 87.07 \%$.

Conclusion: culture, environment, work procedure and supervisory influenced of the adherence safe injection practice among the nurses. (96.05\%) variable independent influence of the adherence safe injection practice among the nurses, within $87.07 \%$ showed good predicted.

\section{Introduction:-}

Injection practices was common medical procedure done by nurses according doctor's prescription. Doenges M.E., Moorhouse M.F., Murr A.C., (2014) stated in nursing process, injection practice is part of nursing intervention, but injection practices was risky for the health care workers. Mandal J., (2013) reported needle stick injury was happened to the nurses, $18 \%$ due disposal of the needle, and $15 \%$ while draw the blood for laboratory study.

\section{Corresponding Author:-Sobur Setiaman}

Address:-Post Graduate School. Sahid Universitv Jakarta. Indonesia. 
Gholami A., Borji A., Lotfabadi P., Asghari A., (2013) result studied at Iran, 32\% health care worker had experience with the needle stick injury, $45 \%$ experience more than ounce, $39.7 \%$ needle stick injury had reported to the supervisor, with odd ratio 2.4 within shift duty. Needle stick injury not reported could be difficulty during investigation and monitoring the exposure of hepatitis B and HIV from the patient. Reasons why not reported due to work fatigue and high workload among nurses.

Amira C.O., and Awobusuyi J.O., (2014) reported at Nigeria, incident needle stick injury 24.5\%/years, ounce needle stick injury (40.2\%). Causes of the needle stick I injury due recapping of the needle (45\%), while disposed of the needle $(30 \%)$, and while inserted the intravenous infusion $(27.5 \%)$. Needle stick injury reported to the superior $(37 \%)$.

Study reported by Kaphle H.P., Poudel S., Subedi S., Gupta N., Jain V., Paudel P., (2014) at the Nepal, 30.5\% nurses had training of safe injection practice, had vaccination anti Hepatitis B (76,8\%), awareness to the needle stick injury $(57,7 \%)$, had experience needle stick injury $(71,8 \%)$, needle stick injury $(55,1 \%)$, while recapping the needle $(94,1 \%)$. Conclusion from there studied needle stick injury incident due of lack of awareness, lack of skill on the safe injection practice.

Study reported done by Holla R., Unnikrishnan B., Ram P., Thapar R., Mithra P., Kumar N., Kulkarni V., Darshan B.B., (2014) incident rate needle stick injury at India $71.9 \%$ (n 136), correlated to the long hour duty. Long hour duty can be caused of the fatigue, fatigue had rick of the needle stick injury.

Reported by Jahangiri M., Rostamabadi A., Hoboubi N., Tadayon N., Soleimani A., (2016) needle stick injuty in Iran, $(76 \%)$ to the nurses, while dealing with the needle before the injection procedure $(85.5 \%)$, recapping the needle $(41.4 \%)$, and not reported $(46,7 \%)$, significant due long hours duty and shift work.

Reported by Gyawali S., Rathore D.S., Shankar P.R., Kumar K.V., Jha N., Sharma D., (2016) at Nepal 75.6\% nurses rural hospital, $39.2 \%$ nurses city hospital had developed with the sign and symptom of hepatitis. $13.3 \%$ nurses at city hospital had hepatitis B positive, 37.3\% nurses from rural hospital had hepatitis B positive. $33.3 \%$ rural nurses, $21.6 \%$ nurses for the city hospital had needle stick injury.

DC (2013), predicted health care worker has no hepatitis B vaccination, exposed by hepatitis B 6\%-30\%, hepatitis C $1.8 \%$ and exposed by HIV 0.3\%. Papadakis M., and McPhee, SJ., (2015), stated that Hepatitis B is infectious disease at the liver by the virus of hepatitis type B.

Dafaalla M.D., Suliman A., Kheir A.E.M., Abdalla M., Hashim A., Mohammed N., Mirghani M., Nimir M., Haroon M., ElHag H., Shadad E., Dafaalla M., Abdalrahman I., (2016) reported that Sudani nurses, 2.3\% not wearing hand glove while injection procedure, $95.9 \%$ believed inf had needle stick injury will hepatitis infected, 99\% believed needle stick injury high risk HIV infected, 83\% nurse feeling worry exposed by HIV and hepatitis if had needle stick injury, $77.8 \%$ hand wash when had needle stick injury, 36,5\% stated sharp box not enough stock, $31.8 \%$ believe needle stick can be prevented.

Bijani M., Khatereh Rostami K., Momennasab M.,Yektatalab S., (2017) reported the impact the safe injection practice training for nurses, incident needle stick injury reduced from $15 \%$ became $10 \%$ with significant $(\mathrm{P}=0,002)$. Di conclusion these study, safe injection practice training can be prevent of incident of needle stick injury among the nurses.

According Strank, J., (2013) adherence to the work procedure influence by behavior factors, component the behavior ass follow: 1 . attitude; 2. motivation; 3. perception; 4. memory of procedure; 5 . individual characteristics; and 6. social background. Based on the theory of Lawrence Green cite by Dafaalla M.D., Suliman A., Kheir A.E.M., Abdalla M., Hashim A., Mohammed N., Mirghani M., Nimir M., Haroon M., ElHag H., Shadad E., Dafaalla M., Abdalrahman I., (2016), and DiClemente R.J., Salazar L.F., Crosby R.A., (2013), behavior influence by 3 factors: 1. Predisposition factor such as attitude, skill, culture, believe and individual characteristics; 2. Enabling factor such as facility, and work environment; 3. Reinforcing factor such as rule and supervisory from the management, and written procedure have to in place.

Problem Statement 
According the theory of infection prevention and control and also data empiric needle stick injury, what is factors influence to adherence safe injection practice among nurses in Healthcare facility Qatar?

Aim of the research

Purpose this study is to analysis of the factor influence adherence to safe injection practice among the nurses at Healthcare Center Qatar. Specific purposes are to follow:

1. To analysis relationship of individual characteristics, knowledge, attitude, availability work facility, work environment, supervisory and work procedure to adherence safe injection practice procedure among the nurses at Healthcare Center Qatar.

2. To analysis factors determinant of individual characteristics, knowledge, attitude, availability work facility, work environment, supervisory and work procedure to adherence safe injection practice procedure among the nurses at Healthcare Center Qatar.

\section{Research benefit}

Benefit of this study are the followed:

1. Identified factors determinant of adherence to the safe injection practice among the nurses.

2. Provided information of the aspect knowledge, attitude, availability work facility, and work environment, supervisory and work procedure to prevention of needle stick injury.

3. Make sure the nursing competency in safe injection practice to be follow by nurses.

\section{Literature view}

\section{Theory Safe Injection Practice}

Recommendation of Gyawali S., Rathore D.S., Shankar P.R., Kumar K.V., (2013) safe injection procedure, at least not harm full to the patient, not risk to the nurses, and reduce exposed medical waste to the community. Moller N., Hansson S.O., Holmberg J.E., Rollenhagen C., (2018), WHO dan ILO (2018), HSE UK (2013) describe, directly caused of the needle stick injury were two thing, unsafe act and unsafe condition. Unsafe act can be prevent by wearing personal protective equipment, by trained nurses in safe injection practice, using sharp box. Make sure all staff adherence to safe injection procedure, will improved quality patient safety program. Gyawali S., Rathore D.S., Shankar P.R., Kumar K.V., (2013) reported, at developing country founded 75\% syringe and needle was contaminated, shelling old needle for children toy, this condtion is categories unsafe condition for everyone, founded sharp box already full and keep on open.

\section{Safe injection practice to the patient}

Recommendation from WHO and ILO (2018) and Kaphle H.P., Poudel S., Subedi S., Gupta N., Jain V., Paudel P., (2014) safe injection practice for the patient, must be using the syringe and needle injection on sterile and disposable, cover of the syringe and needle keep in intact before use, right medicine and doses following doctor's prescription, and also all nurse must trained well in safe injection practice procedure. Kim I., Park M.J., Park M.Y., Yoo H., Choi J., (2013); Brasaite, I., (2016); WHO (2016) describe, with the following patient safety standard, will be increase the positive patient perception.

\section{Safe injection practice to the nurses}

CDC (2013) dan Gholami A., Borji A., Lotfabadi P., Asghari A., (2013) described that the injection supply in nursing practice high risk become needle stick injury if not manage well. Unsafe behavior while dealing with the needle had been proved its can be prick to the finger of nurses while recapping the needle and if not disposed immediately to the sharp box after using it. 30 infection disease can be transmitted within the needle, especial if the patient has positive hepatitis B and HIV positive.

\section{Safe of needle injection to the community}

Nurses Association of New Brunswick (2014) and Royal College of Nursing (2017) recommended, old needle must dispose with the safe procedure, otherwise will misuse by the community for the children for the toy, or recycling the old needle and shelling back by community to the healthcare facility is very danger. Using sharp box and dispose to the incinerator is the way to prevention exposure old needle to the community.

\section{Theory of Adherence}

Adherence means to follow or obey to the instruction, rule and discipline. Adherence in nursing practice were the nurse always followed and obey and implemented the work procedure. Theory planned behavior formulated by 
Ajzen from University of Massachusetts (1985), person will do planned behavior but influence by the following 3 factors: 1. Factor of attitude toward behavior. Positive attitude will increased the adherence, negative attitude will not; 2 . Factor of subjective norm. Work regulation and procedure will follow by the staff as guideline to work; 3 . Factor of behavior control. Command and control is part of managing people. Program safety supervisory must implement to make sure all staff to follow the written procedure.

According health behavior developed by Dr Lawrence Green, described Brasaite, I., (2016), health behavior influence by 3 factors: 1 . Predisposition factor such as attitude, skill, culture, believe and individual characteristics; 2. Enabling factor such as facility, and work environment; 3. Reinforcing factor such as rule and supervisory from the management, and written procedure have to in place.

Factors influence to adherence Safe Injection Practice were included:

1. Individual characteristics: Persons had heredity character, when growth up will be influenced by environment. Born with sex type, with external factor were influence to the person such as the education married status and work experience.

2. Knowledge: Ali M., dan Asrori M., (2014), knowledge is something acknowledgement by natural. Sources of knowledge mostly from the life experience and deep of though. Knowledge created from something known had been observed by common sense. Sight, hear, taste and feeling part of the commons sense. Most common were by sight and hear it.

3. Attitude: Attitude are the behavior determinant, related to perception, personality and motivation. Attitude are the response with mental alertness to the any situation, learn and organize by experience, and cause the person reacted to the object, any situation and with whom contacted.

4. Culture: Culture are the habits of person or organization, violation to the habit, there is not sanction, by morality the habit must be followed and obey by the members of organization (Robbins, S.P., dan Judge, T.A., 2016)

5. Facility: Law No. 1 year of 1970 article 14.c management must be provided PPE and work facility to the employees. Organization must be ruled and regulated of workplace according the health safety expert.

6. Supervisory: Supervisory are the part of the management function, to make sure the employee are working according the work plan. Effective supervisory means, all supervisor must do check, inspection, controlling any work activity, rule out, prevention from the work deviation.

7. Work procedure: Work procedure are the tool of management decision. Work procedure will guide you how to do work. Work procedure will be standardized how to do work.

8. Work environment: Work environment are the location where a task is completed. When pertaining to a place of employment, the work environment involves the physical and work social climate as well as the immediate surroundings of the workplace.

\section{Framework of theory and research}

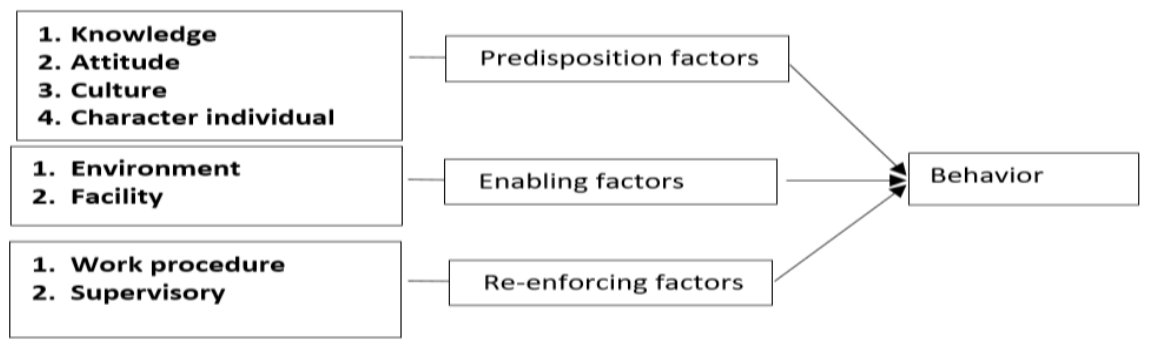

Picture 2.4 Theory Lawrence Green. 


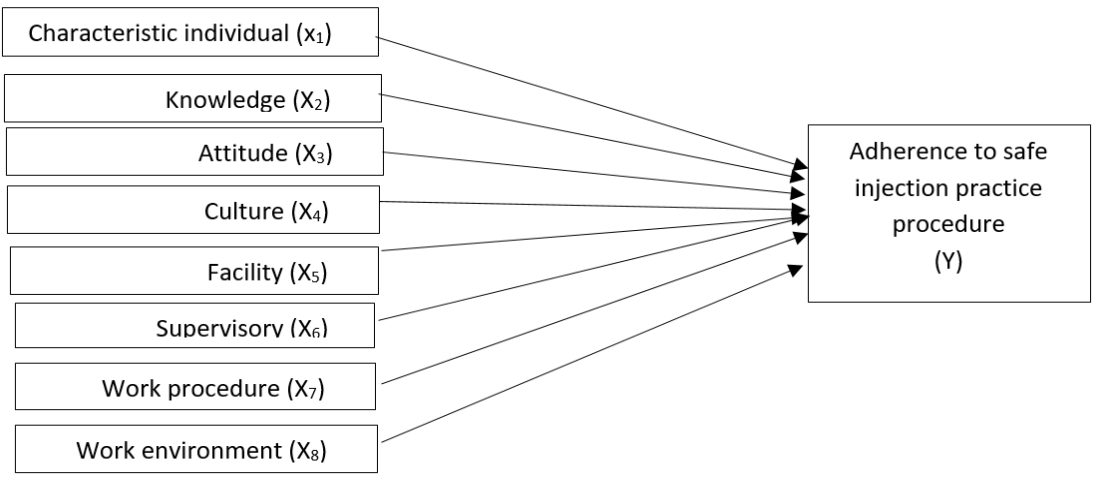

Picture 2.5 Framework of the research

\section{Framework of measurement model}

Measurement model were relation between variable latent. Variable latent in this research as follow bellow: 1. Variable knowledge with 10 indicators; 2. Variable attitude within 6 indicators; 3. Variable culture within 6 indicators; 4. Variable facility within 6 indicators; 5. Variable supervisory within 6 indicators; 7. Variable characteristic individual within 3 indicators; 8. Variable work environment 6 indicators; Variable work procedure within 6 indicators; and Variable adherence safe injection practice within 5 indicators.

\section{Hypothesis}

1. Hypothesis null (Ho): Characteristic individual, attitude, culture, facility, supervisory, work environment, work procedure were not influence to adherence safe injection practice among nurses Healthcare Center X Qatar.

2. Hypothesis alternative (Ha): Characteristic individual, attitude, culture, facility, supervisory, work environment, work procedure were influence to adherence safe injection practice among nurses Healthcare Center X Qatar.

\section{Method of the research}

Type of the research were used the quantitative observational analytics, within cross sectional approach. Venue of the research were the Healthcare Center Qatar, since March $1^{\text {st }}$ up to September $1^{\text {st }}$ 2019. Number of population of the nurses were there working at the Ras laffan City 91 nurses, Messahed City 35 nurses, dan Dukhan City 26 nurses within total 152 nurses, only 114 nurses were an acceptable to participated as responder in this research.

\section{Instrument Research}

Questionnaire as the instrument to collecting data regarding of the characteristic individual, knowledge, attitude, culture, facility, supervisory, work environment, work procedure and adherence safe injection practice. Respondent will choose the answer following a Likert scale: $5=$ strongly agree, $4=$ agree, $3=$ neutral, $2=$ disagree, $1=$ strongly disagree.

\section{Validity and Reliability}

Instrument validity a proof following convergent and discriminant of validity. Cut off the validity used were the loading factor value above 0.5 and the discriminant validity used were the average variance extracted (AVE) value above 0.5. (J. F. Hair, G.T.M. Hult, C.M. Ringle, M. Sarstedt, 2017). Cronbach Alpha used for the check the reliability of the construct. Good reliability of the construct must above the 0.7 (N.K Avkiran, C.M. Ringle 2018).

\section{Technic of Analysis Data}

Analysis these data, we using the technic of Partial Least Square Structural Equation Model (PLS-SEM). Steps of technic PLS-SEM following steps bellows:

1. First steps: Designing the Model of Structural (inner model).

2. Second steps: Designing the model of measurement (outer model).

3. Third steps: Construct the path diagram.

4. Fourth steps: Converse of the path diagram to the equation model: Outer model as the outer relation or the measurement model and the Inner model, as the relation between the variable latent or structural model.

5. Fifth steps: Do estimation of the parameter.

6. Six step: Goodness of Fit analysis. 


\section{Seven step: Hypothesis test}

\section{Result and discussion:-}

Brief of view

Research had been completely at Healthcare Center Qatar supporting oil and gas operation. Research conducted since May $1^{\text {st }} 2019$ up to September $1^{\text {st }}$ with number of responder were 114 nurses. Purpose of this research were to find out of factors influence adherence safe injection practice among nurses at Healthcare Qatar. Safe injection practice procedure been implemented in this healthcare to make sure all nurses, patient and community safe from the needle hazard. Safe injection practice procedure will guide the nurses to do prevention and control of exposure from the cross infection and prevention of needle stick injury among nurses and minimize abuse of needle by community.

Most of the responder is male (83.3\%. It is typical nurses hired by company were the male. Male nurses easy going to response any emergency at the site plant or inside industrial area (table no1). Healthcare in industrial area had the ambulance unit, an also sometime the occupational nurse will visit to the workplace to make sure the workplace were healthy condition.

\begin{tabular}{|c|c|c|}
\hline Sex & Frequency & Percentage \\
\hline Female & 19 & $16,7 \%$ \\
\hline Male & 95 & $83,3 \%$ \\
\hline
\end{tabular}

Source: Result analysis data

Level education of responder, majority were graduated from bachelor degree $(52,6 \%)$. $43 \%$ still hold diploma level. According new policy from State of Qatar, minimal qualification for healthcare worker must be graduated from bachelor level. Bachelor level had ability to make decision with professionalism.

\begin{tabular}{|c|c|c|}
\hline Education & Frequency & Percentage \\
\hline Diploma & 49 & $43 \%$ \\
\hline Bachelor degree & 60 & $52,6 \%$ \\
\hline Master degree & 5 & $4,4 \%$ \\
\hline
\end{tabular}

Source: Result analysis data

Age of the responder, variated from 44.9 years old up to 60 years. Age above 30 years old had long enough exposed by work experience as the professionalism (table 3 ).

Table no 3 Distribution of Frequency Age level of Responder (nill4)

\begin{tabular}{lllllll}
\hline Age & Freq. & Percentage & Min & Max & Mean & Std. Dev \\
\hline$<44$ years old & 52 & $45,6 \%$ & 31 & 60 & 44,99 & 4,831 \\
$>45$ years old & 62 & $54,4 \%$ & & & & \\
\hline \multicolumn{5}{c}{ Source: Result analysis data }
\end{tabular}

Average of work experience were 21.3 year as nurses, $63 \%$ above 21 year experience. Minimal experience as nurse in this healthcare facility are 2 years (table 4 ). 
Table no 4 Distribution of Frequency Work experience of Responder (all4)

\begin{tabular}{lllllll}
\hline $\begin{array}{l}\text { Work } \\
\text { experience }\end{array}$ & Frequency & Percentage & Min & Max & Mean & $\begin{array}{l}\text { Std. } \\
\text { Dev }\end{array}$ \\
\hline$<20$ years & 51 & $44,7 \%$ & 9 & 31 & 21,28 & 4,898 \\
$>21$ years & 63 & $55,3 \%$ & & & & \\
\hline \multicolumn{5}{l}{ Source: Result analysis data } \\
\end{tabular}

\section{Validity and reliability result}

Result of the validity testes mostly above $70 \%$, only the individual characteristics showed AVE value 0.51 but the Cronbach's Alpha showed 61.56\%. According some researcher mention if AVE between 0.4 up to 0.7, make sure the validity test above $50 \%$ will consider as accepted.

\begin{tabular}{|c|c|c|c|c|c|}
\hline $\begin{array}{l}\text { Variable } \\
\text { Latent }\end{array}$ & AVE & $\begin{array}{l}\text { Composite } \\
\text { Reliability }\end{array}$ & $\begin{array}{l}\text { Cronbach' } \\
\text { s Alpha }\end{array}$ & $\begin{array}{c}\text { Cross } \\
\text { validity } \\
\text { Communality }\end{array}$ & $\begin{array}{c}\text { Cross } \\
\text { validity } \\
\text { Redundancy }\end{array}$ \\
\hline $\begin{array}{l}\text { Individual } \\
\text { characteristics }\end{array}$ & 0,5094 & 0,7860 & 0,6156 & 0,5094 & 0 \\
\hline Knowledge & 0,7276 & 0,9638 & 0,9580 & 0,7276 & 0 \\
\hline Attitude & 0,7777 & 0,9545 & 0,9428 & 0,7777 & 0 \\
\hline Culture & 0,7686 & 0,9522 & 0,9398 & 0,7686 & 0 \\
\hline Facility & 0,8196 & 0,9645 & 0,9554 & 0,8196 & 0 \\
\hline Supervisory & 0,7528 & 0,9481 & 0,9343 & 0,7528 & 0 \\
\hline Environment & 0,7777 & 0,9545 & 0,9428 & 0,7777 & 0 \\
\hline $\begin{array}{l}\text { Work } \\
\text { procedure }\end{array}$ & 0,9101 & 0,9838 & 0,9802 & 0,9101 & 0 \\
\hline Adherence & 0,9201 & 0,9857 & 0,9826 & 0,9201 & 0,8705 \\
\hline
\end{tabular}

\section{Significant level result}

Significant test showed if value t-statistic above 1.96 with alpha 0.5 we can conclusion this on significant level. From table no 6 we can see the variable work culture, supervisory, environment and work procedure showed the tstatistic above 1.96, we conclude these variables were significant influence to the adherence safe injection practice. T-statistic individual characteristic, knowledge, attitude and work facility were not significant (bellow 1.96).

\begin{tabular}{|c|c|c|c|c|c|}
\hline Factors & $\begin{array}{l}\text { Sample } \\
\text { Mean }\end{array}$ & $\begin{array}{l}\text { St. } \\
\text { Deviation }\end{array}$ & $\begin{array}{l}\text { St. } \\
\text { Error }\end{array}$ & $\begin{array}{l}\text { T- } \\
\text { Statistic }\end{array}$ & Remarks \\
\hline $\begin{array}{l}\text { Individual characteristics } \\
->\text { Adherence }\end{array}$ & $-0,0151$ & 0,017 & 0,017 & 1,2863 & Not Significant \\
\hline Knowledge -> Adherence & 0,0384 & 0,1159 & 0,1159 & 0,2087 & Not Significant \\
\hline Attitude -> Adherence & $-0,2138$ & 0,1803 & 0,1803 & 1,3506 & Not Significant \\
\hline Facility -> Adherence & 0,1661 & 0,1209 & 0,1209 & 1,4175 & Not Significant \\
\hline Culture $->$ Adherence & 0,4488 & 0,1702 & 0,1702 & 2,9439 & Significant \\
\hline $\begin{array}{l}\text { Supervisory -> } \\
\text { Adherence }\end{array}$ & 0,2609 & 0,0816 & 0,0816 & 3,1090 & Significant \\
\hline $\begin{array}{l}\text { Environment -> } \\
\text { Adherence }\end{array}$ & $-0,2456$ & 0,1514 & 0,1514 & 1,9907 & Significant \\
\hline $\begin{array}{l}\text { Work procedure -> } \\
\text { Adherence }\end{array}$ & 0,5704 & 0,163 & 0,163 & 3,8147 & Significant \\
\hline
\end{tabular}

\section{Determinant Level}

$\mathrm{R}^{2}$ variable adherence were showed $96.05 \%$ with $\mathrm{Q}^{2}$ 87.07\%. 96.05\% variable of culture, environment, supervisory, and work procedure were influenced of the adherence safe injection practice among the nurses within predictive relative $87.07 \%$. 


\section{Conclusion:-}

Conclusion of this research had been proof, those variable work culture, supervisory, environment and work procedure showed the t-statistic above 1.96 we conclude these variables were significant influence to the adherence safe injection practice.

We rejected the hypothesis null. Variable individual characteristic, knowledge, attitude and work facility were not significant influence to adherence safe injection practice.

\section{Recommendation}

1. Future research must concentrate to analyze of the implication the nurse supervisor role and work culture on prevention and control of the infection among nurses.

2. Keep maintenance of the skill head nurse in supervisory skill trough effective communication among nurses for prevention and control of needle stick injury.

3. To implement the work procedure, also need work culture well. Work culture may be improved with management commitment, team work and organizational learning.

4. Work procedure must clear written and socialize with the staff to make sure staff nurse able to follow.

5. Work environment not only the physical environment, also need good climate among nurses and the management.

\section{Reference:-}

1. Adefolalu, A. O., (2018). Cognitive-behavioral theories and adherence: Application and relevance in antiretroviral therapy. S Afr J HIV Med. 2018;19(1), a762. http://doi. org/10.4102/sajhivmed. v19i1.762. Page 1 of 7.

2. Ali M., dan Asrori M., (2014) Metodologi \& Aplikasi Riset Pendidikan. Bandung: Bumi Aksara.

3. Amalia R., Widagdo L., Syamsulhuda BM., (2016). Faktor-faktor yang berhubungan dengan tingkat kepatuhan tenaga kesehatan melakukan cuci tangan (Studi kasus di Instalasi Rawat Inap Rajawali RSUP Dr. Kariadi Semarang), Semarang: FKM Undip, JURNAL KESEHATAN MASYARAKAT FKM Undip (e-Journal) Volume 4, Nomor 3, Juli 2016 (ISSN: 2356-3346) http://ejournals1.undip.ac.id/index.php/jkm

4. Amira C.O., dan Awobusuyi J.O., (2014). Needle-stick injury among health care workers in hemodialysis units in Nigeria: a multi-center study. Int J Occup Environ Med 2014;5:1-8.

5. Ajzen, I., (2015). Consumer attitudes and behavior: the theory of planned behavior applied to food consumption decisions. Rivista di Economia Agraria, Anno LXX, n. 2, 2015, P: 121-138

6. Basar Demir B., Özkan T., Demir S., (2019) Pedestrian violations: Reasoned or social reactive? Comparing theory of planned behavior and prototype willingness model. Journal Transportation Research Part F: Traffic Psychology and Behaviour Vol 60, January 2019, Pages 560-572. https://www.sciencedirect.com/science/article/pii/S1369847818304583.

7. Bhargava A., Mishra B., Thakur A., Dogra V., Loomba P., Gupta s., (2013). Assessment of knowledge, attitude and practices among healthcare workers in a tertiary care hospital on needle stick injury. International Journal of Health Care Quality Assurance. Vol. 26 No. 6, 2013. pp. 549-558. Emerald Group Publishing Limited. 09526862. DOI 10.1108/IJHCQA-04-2012-0035

8. Bijani M., Khatereh Rostami K., Momennasab M.,Yektatalab S., (2017). Evaluating the Effectiveness of a Continuing Education Program for Prevention of Occupational Exposure to Needle Stick Injuries in Nursing Staff Based on Kirkpatrick's Model.Journal of the National Medical Association, Volume 110, Issue 5, October 2018, Pages 459-463. https://doi.org/10.1016/j.jnma.2017.11.002

9. Brasaite, I., (2016). Health Care Professionals'Knowledge and Attitudes Regarding Patient Safety and Skills for Safe Patient Care. Academic dissertation. School of Health Sciences of the University of Tampere, for public discussion in the Jarmo Visakorpi auditorium of the Arvo building, Lääkärinkatu 1, Tampere, on 17 June 2016.

10. CDC (2013). Infection Control; What is the risk of infection after an occupational exposure? (online) di unduh dari: http://www.cdc.gov/oralhealth/infectioncontrol/faq/bloodborne_exposures.htm

11. Dafaalla M.D., Suliman A., Kheir A.E.M., Abdalla M., Hashim A., Mohammed N., Mirghani M., Nimir M., Haroon M., ElHag H., Shadad E., Dafaalla M., Abdalrahman I., (2016). Knowledge, attitude and practice towards needle stick injury among health care workers in a tertiary Sudanese hospital. South American Journal of Clinical Research Volume 3, Issue 1, 2016.

12. Departemen Pendidikan Nasional ( 2012) Kamus Besar Bahasa Indonesia. Jakarta: Balai Pustaka. 
13. DiClemente R.J., Salazar L.F., Crosby R.A., (2013). Health Behavior Theory for public health, principles, foundations, and applications. Maryland: Publisher by Jones and Bartleet Learning.

14. Dieker A.C.M., IJzelenberg W., Proper K.I., Burdorf A., Ket J.C.F., Van der Beek A.J., Hulsegge G., (2019). The contribution of work and lifestyle factors to socioeconomic inequalities in self-rated health - a systematic review. Scand J Work Environ Health 2019;45(2):114-125. doi:10.5271/sjweh.3772.

15. Doenges M.E., Moorhouse M.F., Murr A.C., (2014). Nursing Care Plans Guidelines for Individualizing Client Care Across the Life Span. Philadelphia: Copyright (C 2014 by F. A. Davis Company. US.

16. Febrianawati Yusup (2018). Uji Validitas dan Reliabilitas instrument Penelitian Kuantitatif. Jurnal Tarbiyah: Jurnal Ilmiah Kependidikan e-ISSN: 2548-8376 Vol. 7 No. 1. Januari - Juni 2018

17. Garson G. David. 2016. Partial Least Square-Structural Equation Model. Copyright @e 2016 by G. David Garson and Statistical Associates Publishing.

18. Gholami A., Borji A., Lotfabadi P., Asghari A., (2013). Risk Factors of Needle stick and Sharps Injuries among Healthcare Workers. International Journal of Hospital Research 2013, 2(1):31-38 www.ijhr.iums.ac.ir.

19. Gulilat K., Tiruneh G., (2014). Assessment of knowledge, attitude and practice of health care workers on infection prevention in health institution Bahir Dar city administration. Science Journal of Public Health. 2014; 2(5): 384-393. Published online August 10, 2014 (http://www.sciencepublishinggroup.com/j/sjph) doi: 10.11648/j.sjph.20140205.13. ISSN: 2328-7942 (Print); ISSN: 2328-7950 (Online)

20. Gyawali S., Rathore D.S., Shankar P.R., Kumar K.V., (2013). Strategies and challenges for safe injection practice in developing countries. J Pharmacol Pharmacother. 2013 Jan-Mar; 4(1): 8-12.

21. Gyawali S., Rathore D.S., Shankar P.R., Kumar K.V., Jha N., Sharma D., (2016). Knowledge and Practice on Injection Safety among Primary Health Care Workers in Kaski District, Western Nepal. Malays J Med Sci. 2016 Jan; 23(1): 44-55.

22. Hair J.F., Hult G.T.M., Ringle C.M., Sarstedt M., (2017). A primer on partial least squares structural equation modeling (2nd ed.), Sage, Thousand Oakes, CA.

23. Hair, J. F., Sarstedt, M., Ringle, C. M., and Gudergan, S. P. (2018). Advanced Issues in Partial Least Squares Structural Equation Modeling (PLS-SEM). Thousand Oaks, CA: Sage.

24. Holla R., Unnikrishnan B., Ram P., Thapar R., Mithra P., Kumar N., Kulkarni V., Darshan B.B., (2014). Occupational Exposure to Needle Stick Injuries among Health Care Personnel in a Tertiary Care Hospital: A Cross Sectional Study. J Community Med Health Educ 2014, S2:004.

25. Haas, Emily Joy. (2019). The Role of Supervisory Support on Workers' Health and Safety Performance. Journal Health Communication. 2019/01/04 doi: 10.1080/10410236.2018.1563033. https://doi.org/10.1080/10410236.2018.156303

26. HSE UK (2013). Behavior Based Safety Guide. Published by the Health and Safety Authority, Dublin: Published by The Metropolitan Building, James Joyce Street.

27. Iriviranty A., Ayuningtyas D., M. Misnaniarti, 2016. Evaluation of Patient Safety Culture and Organizational Culture as a Step in Patient Safety Improvement in a Hospital in Jakarta, Indonesia. Patient Saf Qual Improv. 2016; 4(3):394-399.

28. Ismail AA, Mahfouz MS, Makeen A., (2014). Injection safety among primary health care workers in Jazan region, Saudi Arabia. Int J Occup Environ Med 2014;5:-163.

29. Jackson, M., (2015). The History of Medicine: A Beginner's Guide. Social History of Medicine, Volume 28, Issue 2, 1 May 2015, P: 423-424, London: Oneworld Publication.

30. Jahangiri M., Rostamabadi A., Hoboubi N., Tadayon N., Soleimani A.,(2016). Needle stick Injuries and their Related Safety Measures among Nurses in a University Hospital, Shiraz, Iran. Safety and Health at Work 7 (2016) $72-77$.

31. Joel M. Haight J.M., (2013). Handbook of Loss Prevention Engineering. Weinheim, Germany: Published Wiley-VCH Verlag GmbH \& Co. KGaA, Boschstr. 12, 69469

32. Kaphle H.P., Poudel S., Subedi S., Gupta N., Jain V., Paudel P., (2014). Awareness and Practices on Injection Safety among Nurses Working in Hospitals of Pokhara, Nepal. Nepal: International Journal of Medical and Health Sciences,3 (4), 301-307.

33. Kim I., Park M.J., Park M.Y., Yoo H., Choi J., (2013). Factors Affecting the Perception of Importance and Practice of Patient Safety Management among Hospital Employees in Korea. Marland USA: Published by Asian Nursing Research 7.

34. Kim S.A., Oh H.S., Suh Y.O., Seo W.S., (2014). An Integrative Model of Workplace Selfprotective Behavior for Korean Nurses. Asian Nursing Research 8 (2014) P:91-98. Copy right Korean Society of Nursing Science.

35. Lin C.F., Huang C.I., Yang C.M., Lu M.S., (2019). The Relationship Between Work Environment Satisfaction and Retention Intention Among Nursing Administrators in Taiwan. Journal of Nursing Research. Publish Ahead 
of Print(): FEB 2019. DOI: 10.1097/JNR.0000000000000312, PMID: 30807442. Issn Print: $1682-3141$. Publication Date: 2019/02/01

36. Lowry P.B., dan Gaskin J., (2014) Partial Least Squares (PLS) Structural Equation Modeling (SEM) for Building and Testing Behavioral Causal Theory: When to Choose It and How to Use It. IEEE Transactions on Professional Communication, Vol. 57, No. 2, June 2014

37. Manaf RA., Rahmawati H.T., Syukran I. M., Amirah A.I., (2015). Knowledge, Attitude, and Practice regarding work safety culture among staff in the Faculty of Medicine and Health Sciences, Universiti Putra Malaysia. International Journal of Public Health and Clinical Sciences e-ISSN : 2289-7577. Vol. 2:No. 5 September/October 2015

38. Mondal, J. (2013) Needle Stick Injury: A major occupational hazards among the health care workers in Nepal. Nepal: International Journal of Occupational Safety and Health, 3(1), $22-25$.

39. Motaarefi H., Mahmoudi H., Mohammadi E., Dehkordi A.H., (2016) Factors Associated with Needlestick Injuries in Health Care Occupations: A Systematic Review. J Clin Diagn Res. 2016 Aug; 10(8): IE01-IE04.

40. Moller N., Hansson S.O., Holmberg J.E., Rollenhagen C., (2018). Handbook of Safety Principles. New Jersey, USA: Published by John Wiley \& Sons, Inc., 111 River Street, Hoboken.

41. N.K. Avkiran, C.M. Ringle (2018). PLS-SEM Recent Advances in Banking and Finance. International Series in Operations Research and Management. Swiss:Springer

42. Nurses Association of New Brunswick (2014). Standards for Infection Prevention and Control Revised October 2014 (2/15), Canada: NURSES ASSOCIATION OF NEW BRUNSWICK.

43. OSHA, (2015). OSHA Safety and Health Program Management Guidelines. http://www.osha.gov

44. Papadakis M., dan McPhee, SJ., (2015). Current Medical diagnosis and treatment 2015, Illinois, USA: Copyright by McGraw-Hill Education.

45. Passmore, J., (2016). Wiley Blackwell Handbooks in Organizational Psychology. This edition first. Sussex, UK: published by John Wiley \& Sons, Ltd, Registered Office. John Wiley \& Sons Ltd.

46. Perusahaan X Qatar, (2018). Safe injection practice survey Report. Doha Qatar: Comparative study Safety Injection Practice working Group.

47. Rahmawanti NR., Swasto B., Prasetya A., (2014). Pengaruh lingkungan kerja terhadap kinerja karyawan (Studi pada Karyawan Kantor Pelayanan Pajak Pratama Malang Utara). Jurnal Administrasi Bisnis (JAB)| Vol. 8 No. 2 Maret 2014, administrasibisnis.studentjournal.ub.ac.id

48. Robbins, S.P., dan Judge, T.A., (2016) Organizational Behavior. Copyright by Pearson Education, Inc., publishing as Prentice Hall .

49. Royal College of Nursing (2017). Essential Practice for Infection Prevention and Control Guidance for nursing staff. Londond: Published by the Royal College of Nursing, 20 Cavendish Square, London.

50. Sakti F.T., Fauzia S.N., (2018). Pengaruh Pengawasan Pajak Hotel Terhadap Tingkat Kepatuhan Wajib Pajak (Studi Kasus Pada Badan Pendapatan Daerah Kabupaten Garut). JISPO: Jurnal Ilmu Sosial dan Ilmu Politik Vol.8 No. 1 Edisi Januari- Juni tahun 2018

51. Vazquez C.E., (2019) Successful work cultures: recommendations for leaders in healthcare. Journal Leadership in Health Services, Vol. 32 Issue: 2, pp.296-308, https://doi.org/10.1108/LHS-08-2018-0038

52. WHO dan ILO (2018). Occupational safety and health in public health emergencies: a manual for protecting health workers and responders. Geneva: Copyright (C) International Labour Organization.

53. WHO (2016). Best Practices in Patient Safety 2nd Global Ministerial Summit on Patient Safety. Geneva: Copyright (C) International Labour Organization.

54. Williams L.J., Gavin M.B., Hartman N.S., (2015) Structural equation model methods in strategy research: application and issues. In Research Methodology in Strategy and Management. Published online: 10 Mar 2015; 303-346. 